\title{
Monitoring of emaciation disease in cultured Paralichthys olivaceus of Jeju island during 2014-2015
}

\author{
Seung Min Kim¹, Lyu Jin Jun' ${ }^{1}$ Da Won Lee ${ }^{1}$, Hyun Kyung Park', Hyun Do Jeong ${ }^{2}$, Jong Sung Kim³
} and Joon Bum Jeong ${ }^{1 *}$ (D)

\begin{abstract}
This study investigated the trend in emaciation infection outbreak in olive flounder (Paralichthys olivaceus) of Jeju island, South Korea, during 2014-2015. A total of 900 fish were systematically examined by PCR method using the EM-F/EM-R primer set in April, May, September, November, and December 2014, and the infection rate was recorded. In 2015, the same examination was conducted in March, May, July, and October but with 660 fish. It was found that the infection rate was 18.3 71.6\% in 2014, which increased to 16.3 90.3\% in 2015. Furthermore, September and December in 2014 and March, July, and October in 2015 showed a relatively higher infection rate. According to the infection trend analysis, which depended on the sample size, the infection occurred in all of fish sizes in this study and $11 \sim 30 \mathrm{~cm}$ fish group showed the highest infection rate. Histological examination confirmed that the kidney areas of the emaciating infected olive flounder contained several spores of $4 \sim 9 \mu \mathrm{m}$, and in severe cases, the elimination and destruction of tissue were confirmed by PCR. Thus, an important portion of farmed olive flounders in the Jeju region suffers from emaciation disease. This epidemiological survey serves as a useful reference on the emaciation disease of cultured olive flounders in Jeju.
\end{abstract}

Keywords: Emaciation disease, Olive flounder, Jeju

\section{Background}

Since the 1990s, a variety of seawater fish has been actively cultivated and, consequently, the global volume and diversity of live fish imports have dramatically increased. However, in Korea, due to an imperfect quarantine system, accidental disease importation via marine seedlings and the introduction of parasites that previously did not exist in the country are becomingly increasingly problematic (Chun 2006). Various pathogens have been causing mixed infectious diseases and massive deaths of fishes regardless of water temperature (Kim et al. 2006). In recent years, as the possibility of the inflow of foreign diseases has increased, there has been an increasing number of studies that generally monitor the diseases or investigate the correlation with diseases (Cho et al. 2009; Jung et al. 2012; Song et al.

\footnotetext{
* Correspondence: jeongjb@jejunu.ac.kr

${ }^{1}$ Faculty of Marine Biomedical Science, Jeju National University, Jeju 63243,

South Korea

Full list of author information is available at the end of the article
}

2013). However, until now, most of the research done on domestic fish farming have only been focused on specific diseases, and research on the disease of unknown cause is yet considered minor (Kim et al. 2006; Cho et al. 2008; Kim et al. 2010).

Olive flounder (Paralichthys olivaceus) is among the key commercial marine finfish species cultured in Korea and Japan. Recently, there has been an unknown plague occurring among the $\sim 20$-cm length olive flounders within fish farms in Jeju Island, South Korea. The death rate of olive flounders occurring within 1-3 weeks after the first symptoms appear is increasing. Fish infected with this illness show darkening of the body color, a decrease in weight, and bleeding (Kim et al. 2015). The myxosporean emaciation disease has occurred in tiger puffer (Takifugu rubripes), parrotfish (Sparisoma cretense), and olive flounder (Ishimatsu et al. 2007; Katharios et al. 2014; Yasuda et al. 2005). Although external symptoms including abdominal emaciation and body darkening were observed, there is no clear information on exact life cycle 
has not been reported. In addition, PCR analysis of the olive flounders of Jeju island with the primer set of Enteromyxum leei (1589 bp), an etiologic agent of turbot myxosporean emaciation disease in Japan, a neighboring country of Korea, ruled out E. leei as the etiologic agent, as a negative reaction was observed (Kim et al. 2015). We designed the specific primer set for detection of myxosporea from emaciated olive flounder in Korea (Kim et al. 2015). However, there have been no reports yet on the trend of emaciation occurrence in Korea. According to the World Organization for Animal Health (OIE), to establish effective countermeasures against diseases arising in fish farms, accurate monitoring of the occurrence of diseases should be done at each farm (OIE 2008).

Therefore, in this study, 60 olive flounder farms in Jeju island were investigated to determine the status of emaciation infection in 2014 2015. The rate of infection was investigated using PCR, to provide fundamental data on the frequency of occurrence by month season and by the size of the fish.

\section{Methods}

Monitoring of emaciation of olive flounders in fish farms in 2014

In order to investigate the emaciation occurrence, monitoring from 60 fish farms was performed five times a year in April, May, September, November, and December 2014. The surveyed areas are shown in Fig. 1. Randomly collected three olive flounders (P. olivaceus) $(5 \sim 600 \mathrm{~g})$, not considering whether or not the fish were diseased, from 60 fish farms in Jeju-si and Seogwipo-si of Jeju-do with 180 fish were investigated each time. There was the highest density of band in PCR test using the kidney tissue of emaciated olive flounder (data not shown), and the kidney tissues of 900 fish were investigated by PCR method as described below. The water temperature was measured using a YSI 650XL water quality meter (YSI, USA) (Table 1).

\section{Monitoring of emaciation of olive flounders in fish farms in 2015}

In 2015, it was difficult to collect in few farms and sample collection was not same in 2014. The kidney tissues of 660 fish were taken from 60 fish farms collected from March to April, 55 fish farms from May to June, 52 fish farms from July to August, and 53 fish farms in October and investigated by PCR method as described below. The infection rates in 2015 were investigated using an equivalent method to that used in 2014 (Table 2).

\section{DNA extraction}

DNA was extracted from the kidney tissue of sampled olive flounder using the DNeasy ${ }^{\circ}$ Blood and Tissue kit (Qiagen Hilden, Germany), as described by Kim et al. (2015). First, $180 \mu \mathrm{L}$ ATL buffer and $20 \mu \mathrm{L}$ proteinase $\mathrm{K}$ were added to the kidney samples, and then the solution was left at $56{ }^{\circ} \mathrm{C}$ until completely dissolved. After the reaction, $200 \mu \mathrm{L}$ AL buffer and $200 \mu \mathrm{L}$ ethanol (100\%) were added. The mixed solution was then placed in a spin column and centrifuged at 6,000 $\times g$ for $1 \mathrm{~min}$, after which the column was placed in a new tube. The column was washed with $500 \mu \mathrm{L}$ AW1 buffer and $500 \mu \mathrm{L}$ AW2 buffer, and DNA was separated by adding $50 \mu \mathrm{L}$ AE buffer. The separated DNA was stored at $80^{\circ} \mathrm{C}$ until further analysis.

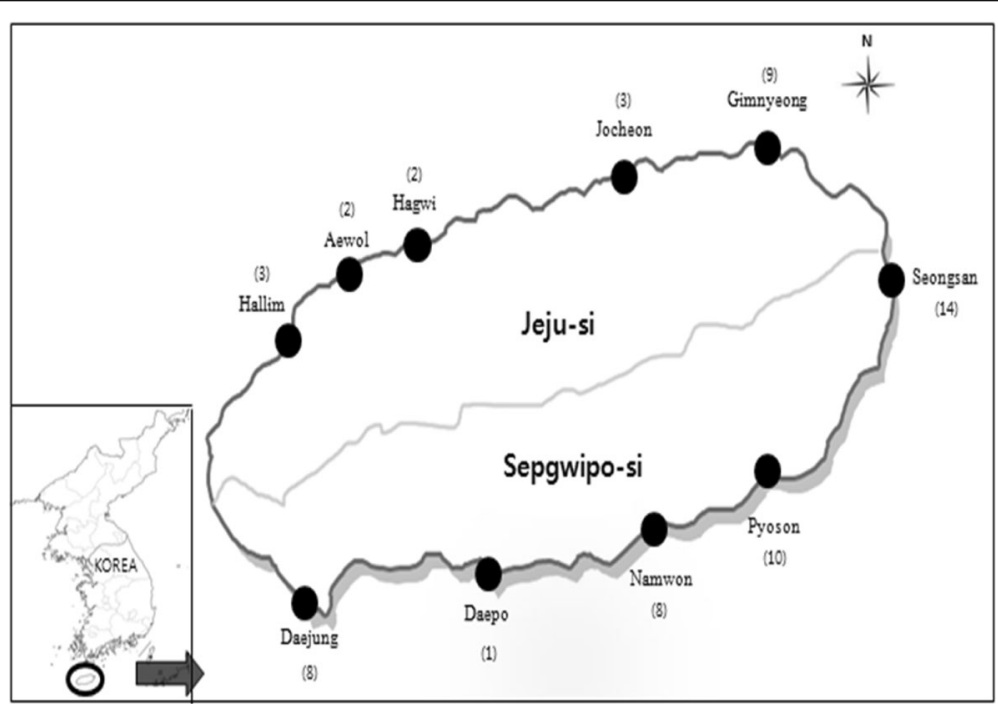

Fig. 1 Location of the sampling sites in this study 
Table 1 Sample information employed for the investigation of emaciation infection in rearing olive flounder ( $P$. olivaceus) of Korea in 2014

\begin{tabular}{|c|c|c|c|c|c|}
\hline Year & Month & Water temp. $\left({ }^{\circ} \mathrm{C}\right)$ & No. of Fish & No. of farm & Fish size \\
\hline \multirow[t]{20}{*}{2014} & \multirow[t]{4}{*}{ Apr } & \multirow[t]{4}{*}{$16.4 \pm 0.4$} & 30 & 10 & $<10 \mathrm{~cm}$ \\
\hline & & & 54 & 18 & $11 \sim 20 \mathrm{~cm}$ \\
\hline & & & 54 & 18 & $21 \sim 30 \mathrm{~cm}$ \\
\hline & & & 42 & 14 & $31 \mathrm{~cm}<$ \\
\hline & \multirow[t]{4}{*}{ May } & \multirow[t]{4}{*}{$17.4 \pm 0.6$} & 21 & 7 & $<10 \mathrm{~cm}$ \\
\hline & & & 93 & 31 & $11 \sim 20 \mathrm{~cm}$ \\
\hline & & & 33 & 11 & $21 \sim 30 \mathrm{~cm}$ \\
\hline & & & 33 & 11 & $31 \mathrm{~cm}<$ \\
\hline & \multirow[t]{4}{*}{ Sep } & \multirow[t]{4}{*}{$20.9 \pm 1.3$} & 0 & 0 & $<10 \mathrm{~cm}$ \\
\hline & & & 18 & 6 & $11 \sim 20 \mathrm{~cm}$ \\
\hline & & & 114 & 38 & $21 \sim 30 \mathrm{~cm}$ \\
\hline & & & 48 & 16 & $31 \mathrm{~cm}<$ \\
\hline & \multirow[t]{4}{*}{ Nov } & \multirow[t]{4}{*}{$18.3 \pm 0.9$} & 3 & 1 & $<10 \mathrm{~cm}$ \\
\hline & & & 6 & 2 & $11 \sim 20 \mathrm{~cm}$ \\
\hline & & & 96 & 32 & $21 \sim 30 \mathrm{~cm}$ \\
\hline & & & 75 & 25 & $31 \mathrm{~cm}<$ \\
\hline & \multirow[t]{4}{*}{ Dec } & \multirow[t]{4}{*}{$16.5 \pm 0.9$} & 0 & 0 & $<10 \mathrm{~cm}$ \\
\hline & & & 15 & 5 & $11 \sim 20 \mathrm{~cm}$ \\
\hline & & & 84 & 28 & $21 \sim 30 \mathrm{~cm}$ \\
\hline & & & 81 & 27 & $31 \mathrm{~cm}<$ \\
\hline Total & & & 900 & 300 & \\
\hline
\end{tabular}

Table 2 Sample information employed for the investigation of emaciation infection in rearing olive flounder ( $P$. olivaceus) of Korea in 2015

\begin{tabular}{|c|c|c|c|c|c|}
\hline Year & Month & Water temp. $\left({ }^{\circ} \mathrm{C}\right)$ & No. of fish & No. of farm & Fish size \\
\hline \multirow[t]{16}{*}{2015} & \multirow[t]{4}{*}{ Mar and Apr } & \multirow[t]{4}{*}{$15.5 \pm 1$} & 45 & 15 & $<10 \mathrm{~cm}$ \\
\hline & & & 69 & 23 & $11 \sim 20 \mathrm{~cm}$ \\
\hline & & & 33 & 11 & $21 \sim 30 \mathrm{~cm}$ \\
\hline & & & 33 & 11 & $31 \mathrm{~cm}$ \\
\hline & \multirow[t]{4}{*}{ May and Jun } & \multirow[t]{4}{*}{$16.7 \pm 0.7$} & 18 & 6 & $<10 \mathrm{~cm}$ \\
\hline & & & 87 & 29 & $11 \sim 20 \mathrm{~cm}$ \\
\hline & & & 39 & 13 & $21 \sim 30 \mathrm{~cm}$ \\
\hline & & & 21 & 7 & $31 \mathrm{~cm}<$ \\
\hline & \multirow[t]{4}{*}{ Jul and Aug } & \multirow[t]{4}{*}{$20.5 \pm 1.7$} & 9 & 3 & $<10 \mathrm{~cm}$ \\
\hline & & & 60 & 20 & $11 \sim 20 \mathrm{~cm}$ \\
\hline & & & 69 & 23 & $21 \sim 30 \mathrm{~cm}$ \\
\hline & & & 18 & 6 & $31 \mathrm{~cm}<$ \\
\hline & \multirow[t]{4}{*}{ Oct } & \multirow[t]{4}{*}{$19.5 \pm 0.5$} & 12 & 4 & $<10 \mathrm{~cm}$ \\
\hline & & & 48 & 16 & $11 \sim 20 \mathrm{~cm}$ \\
\hline & & & 42 & 14 & $21 \sim 30 \mathrm{~cm}$ \\
\hline & & & 57 & 19 & $31 \mathrm{~cm}<$ \\
\hline Total & & & 660 & 220 & \\
\hline
\end{tabular}

PCR

The primers used for PCR were suggested by Kim et al. (2015) (Table 3). PCR reactions contained $0.4 \mu \mathrm{M}$ of each primer, 1X ExTaq reaction buffer, $200 \mu \mathrm{M}$ of each dNTP, $0.5 \mathrm{U}$ of ExTaq DNA polymerase, and $1 \mu \mathrm{l}$ of the respective template DNA. The reaction mixture was completed to $20 \mu \mathrm{L}$ with distilled water. The conditions for one reaction were as follows: pre-denatured at $95{ }^{\circ} \mathrm{C}$ for $3 \mathrm{~min}$, denatured for $30 \mathrm{~s}$, annealed at $55^{\circ} \mathrm{C}$ for $30 \mathrm{~s}$, and then extended at $72{ }^{\circ} \mathrm{C}$ for $30 \mathrm{~s}$. This reaction was repeated for 35 cycles, followed by a post-extension at $72{ }^{\circ} \mathrm{C}$ for $7 \mathrm{~min}$. The PCR amplification product was placed in 1X TAE buffer and electrophoresed after the addition of $0.5 \mu \mathrm{g} / \mathrm{mL}$ ethidium bromide to the $1 \%$ agarose gel as an intercalating agent. The size of the product was then detected under ultraviolet light.

\section{Histopathological examination}

As Kim et al. (2015) observed that the outbreak of emaciation disease in South Korea was reported to be found 4$5 \mu \mathrm{m}$ spores in histological examination, an experiment was performed as follows. The extracted kidney tissues of the olive flounder were fixed in Bouin's solution for $24 \mathrm{~h}$, dehydrated in $70 \%$ ethanol, embedded in paraffin wax (Leica EG 1150HC, Germany), sectioned (4-5 $\mu \mathrm{m}$ thickness) using a microtome (Leica Jung 820, Germany), and placed on glass slides to dry. The prepared samples were stained with hematoxylin and eosin (H\&E) for optical microscopic examination (Zeiss LT60, Germany).

\section{Results}

Infection rates in fish farms by season in 2014

This study investigated the state of emaciation infection in 900 olive flounders collected from 60 fish farms in April, May, September, November, and December 2014, in Jeju Island, South Korea, a prime cultivation site of olive flounders. Although there were symptomatic differences in each fish infected with emaciation, which is seriously affecting the olive flounder farms in the Jeju region, the main external symptoms were darkening of the body color and severe emaciation of the abdominal area. Internal symptoms showed that hepatorrhagia and severe kidney nebula were observed (data not shown).

As a result of the 2014 investigation on the state of infection of olive flounders, 26 fish (14.4\%) of 13 fish farms in April, 12 (6.6\%) of 11 fish farms in May, 44 (24. $4 \%)$ of 32 fish farms in September, 36 (20\%) of 23 fish

Table 3 PCR primers used in this study

\begin{tabular}{llll}
\hline Primer & Oligonucleotide sequence $\left(5^{\prime}-3^{\prime}\right)$ & $\begin{array}{l}\text { Expected } \\
\text { size }\end{array}$ & Reference \\
\hline EM-F & CAACCGCAATGTGTTTACTC & $812 \mathrm{bp}$ & Kim et al. (2015) \\
EM-R & CCAAACAACCTGCCACAATG & & \\
\hline
\end{tabular}


Table 4 Monitoring of emaciation disease for olive flounder (P. olivaceus) farms in 2014

\begin{tabular}{|c|c|c|c|c|c|c|c|}
\hline \multirow[t]{3}{*}{ Year } & \multirow[t]{3}{*}{ Month } & \multicolumn{6}{|c|}{ Detection rate (\%) } \\
\hline & & \multirow[t]{2}{*}{$<10 \mathrm{~cm}$} & \multirow[t]{2}{*}{$11 \sim 20 \mathrm{~cm}$} & \multirow[t]{2}{*}{$21 \sim 30 \mathrm{~cm}$} & \multirow[t]{2}{*}{$31 \mathrm{~cm}<$} & \multicolumn{2}{|l|}{ Total } \\
\hline & & & & & & Fish & Farm \\
\hline \multirow[t]{6}{*}{2014} & Apr & $10(1 / 10)^{a}$ & $22.2(4 / 18)$ & $44.4(8 / 18)$ & $0(0 / 14)$ & $14.4(26 / 180)$ & $21.6(13 / 60)$ \\
\hline & May & $14.2(1 / 7)$ & $9.6(3 / 31)$ & $54.5(6 / 11)$ & $9(1 / 11)$ & $6.6(12 / 180)$ & $18.3(11 / 60)$ \\
\hline & Sep & - & $100(6 / 6)$ & $55.2(21 / 38)$ & $31.2(5 / 16)$ & $24.4(44 / 180)$ & $53.3(32 / 60)$ \\
\hline & Nov & $0(0 / 1)$ & $100(2 / 2)$ & $50(16 / 32)$ & $20(5 / 25)$ & $21.1(38 / 180)$ & $38.3(23 / 60)$ \\
\hline & Dec & - & $100(5 / 5)$ & $75(20 / 28)$ & $62.9(16 / 27)$ & $42.2(76 / 180)$ & $71.6(43 / 60)$ \\
\hline & Total & $11.1(2 / 18)$ & $32.2(20 / 62)$ & $56.6(72 / 127)$ & $30.1(28 / 93)$ & $21.7(196 / 900)$ & $40.6(122 / 300)$ \\
\hline
\end{tabular}

${ }^{\mathrm{a}}$ Number of $\mathrm{PCR}$ positive/number of farm

farms in November, and 78 (43.3\%) of 42 fish farms in December showed a positive PCR reaction (Table 4 and Fig. 2). In addition, various rates of infection by season were shown from spring to winter (Table 4). Among these, the highest infection rate occurred from September (fall) to December (winter), when water temperatures began to decrease (Table 4 ).

\section{Infection rates by size in 2014}

Based on the detected genes, the rate of infection according to the size of the fish was investigated. Consequently, in April, according to fish size, $0 / 14$ fish farms (0\%) in the < $10 \mathrm{~cm}, 4 / 18(22.2 \%)$ in the $11 \sim 20 \mathrm{~cm}, 8 / 18(44.4 \%)$ in the $21 \sim 30 \mathrm{~cm}$, and $1 / 10(10 \%)$ in the $>31 \mathrm{~cm}$ groups, respectively, were infected. The corresponding infection rates in May were $1 / 7$ fish farms $(14.2 \%)$ in the $<10 \mathrm{~cm}$ group, $3 / 31$ (9.6\%) in the $11 \sim 20 \mathrm{~cm}$ group, $6 / 11$ (54.5\%) in the $21 \sim 30 \mathrm{~cm}$ group, and $1 / 11$ (9\%) in the $>31 \mathrm{~cm}$ group. Thus, in April and May, the rate of infection was low for the group $>31 \mathrm{~cm}$.

In September, the infection rates were $6 / 6$ fish farms (100\%) in the $11 \sim 20 \mathrm{~cm}$ group, $21 / 38$ (55.2\%) in the $21 \sim 30 \mathrm{~cm}$ group, and 5/16 (31.2\%) in the $>31 \mathrm{~cm}$ group. Infection rates in November were $0 / 1$ fish farms $(0 \%)$ in the $<10 \mathrm{~cm}$ group, $2 / 2(100 \%)$ in the $11 \sim 20 \mathrm{~cm}$ group, $16 / 32(50 \%)$ in the $21 \sim 30 \mathrm{~cm}$ group, and 5/25 (20\%) in the $>31 \mathrm{~cm}$ group. Comparatively, high infection rates were detected in December, with 5/5 fish farms (100\%), $20 / 28$ (75\%), and 16/27 (62.9\%) in the 11 20, 21 30 and
$>31 \mathrm{~cm}$ groups, respectively. Based on the epidemiological survey conducted from April to December, the rate of infection of domestic emaciation was highest in fish between $21 \sim 30 \mathrm{~cm}$, but it was evident that all sizes of olive flounders were susceptible to infection (Table 4).

\section{Infection rates in $\mathbf{2 0 1 5}$}

As a result of the state of emaciation infection by each fish farm in 2015, the number of fish farms detected with emaciation were 30/60 (50\%) in March April, 9/55 (16.3\%) in May June, 47/52 (90.3\%) in July August, and 45/53 (84.9\%) in October (Table 5 and Fig. 2). In addition, infection rates by fish size were $0 / 15(0 \%)$ in the $<10 \mathrm{~cm}$ group, $13 / 23(47.8 \%)$ in the $11 \sim 20 \mathrm{~cm}$ group, $9 / 11(81.8 \%)$ in the $21 \sim 30 \mathrm{~cm}$ group, and $7 / 11$ $(72.1 \%)$ in the $>31 \mathrm{~cm}$ group, in March April. In May June, the corresponding values were $0 / 6(0 \%), 3 / 29$ (10. $3 \%), 3 / 13(23 \%)$, and $3 / 7(42.8 \%)$ in the $<10,11 \sim 20$, $21 \sim 30$ and $>31 \mathrm{~cm}$ groups, respectively (Table 5).

In addition, in July August, the infection status in the fish farms, based on fish size, were $3 / 3(100 \%)$ in the < $10 \mathrm{~cm}$ group, $19 / 20$ (95\%) in the $11 \sim 20 \mathrm{~cm}$ group, $20 / 23$ (86.9\%) in the $21 \sim 30 \mathrm{~cm}$ group, and $5 / 6(83.3 \%)$ in the > $31 \mathrm{~cm}$ group. Corresponding values in October revealed 1/ 4 (25\%), 14/16 (87.5\%), 13/14 (92.8\%), and 17/19 (89.4\%) in the < 10, 11 20, 21 30, and > $31 \mathrm{~cm}$ groups, respectively. Through the epidemiological survey conducted from March-October, the occurrence of infection was equivalent to that of 2014 in all sizes. However, in 2015, the highest

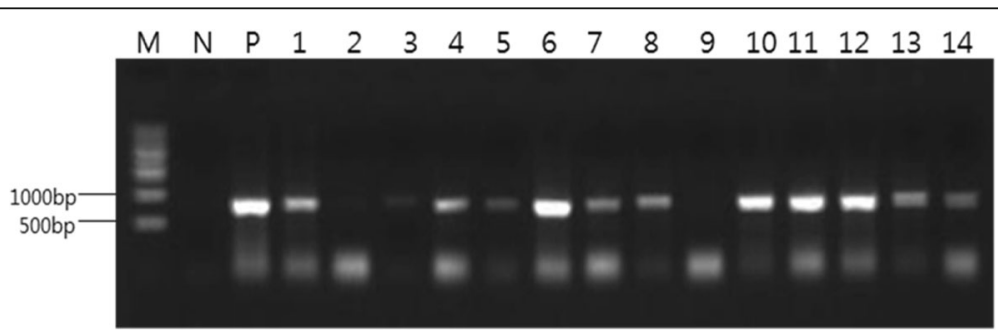

Fig. 2 Gel electrophoresis of the products amplified with the primer set EM-F/R from the extracted sample of the kidney of affected olive flounder cultured in emaciated disease. Lanes 1, 3, 4, 5, 6, 7, 8, 10, 11, 12, 13, and 14, positive samples; Lanes 2 and 9, negative samples; M, 1 kb DNA ladder; N, negative control; $\mathrm{P}$, positive control 
Table 5 Monitoring of emaciation disease for olive flounder (P. olivaceus) farms in 2015

\begin{tabular}{|c|c|c|c|c|c|c|}
\hline \multirow[t]{2}{*}{ Year } & \multirow[t]{2}{*}{ Month } & \multicolumn{5}{|c|}{ Detection rate (\%) } \\
\hline & & $<10 \mathrm{~cm}$ & $11 \sim 20 \mathrm{~cm}$ & $21 \sim 30 \mathrm{~cm}$ & $31 \mathrm{~cm}<$ & Total farm \\
\hline \multirow[t]{5}{*}{2015} & Mar and Apr & $0(0 / 15)^{a}$ & $47.8(13 / 23)$ & $81.8(9 / 11)$ & $72.1(8 / 11)$ & $50(30 / 60)$ \\
\hline & May and Jun & $0(0 / 6)$ & $10.3(3 / 29)$ & $23(3 / 13)$ & $42.8(3 / 7)$ & $16.3(9 / 55)$ \\
\hline & Jul and Aug & $100(3 / 3)$ & $95(19 / 20)$ & $86.9(20 / 23)$ & $83.3(5 / 6)$ & $90.3(47 / 52)$ \\
\hline & Oct & $25(1 / 4)$ & $87.5(14 / 16)$ & $92.8(13 / 14)$ & $89.4(17 / 19)$ & $84.9(45 / 53)$ \\
\hline & Total & $14.2(4 / 28)$ & $55.6(49 / 88)$ & $73.7(45 / 61)$ & 76.7 (33/43) & $59.5(131 / 220)$ \\
\hline
\end{tabular}

${ }^{\mathrm{a}}$ Number of PCR positive/number of farm

infection rate was observed in fish $>31 \mathrm{~cm}$ (Table 5). In addition, periodic infection rates throughout the year were found to be the same as 2014 (Table 5), but a higher infection rate was evident in 2015 than in 2014. Among the months, the highest infection rate was observed in July August, when the water temperature is high, and in October, when the water temperature starts decreasing (Table 5).

\section{Infection rates by weight in 2014 and 2015}

Infection rate in accordance with olive flounder weight in 2014 and 2015 demonstrated that olive flounder of PCR positive with the EM-F/R primer set was lighter 30-40\% compared to olive flounder of PCR negative (Fig. 3).

\section{Histopathological examination of the diseased olive flounder}

Olive flounder with PCR positive showed numbers of 4$9 \mu \mathrm{m}$ round or egg-shaped spores in the kidneys, some parts of destroyed or metamorphosed plasmodium including glomerulus, and nucleus were observed (Fig. 4b). Normal shape of kidneys was found in olive flounder with PCR negative (Fig. 4a).

\section{Discussion}

In 2014, a total of 900 fishes were surveyed for systematic infection rates based on season, fish farm environment, population, and size, to determine the trend in emaciation occurrence. A high rate of infection was observed in 2014. Therefore, it was considered that regular monitoring of emaciation will be needed in 2015. Accordingly, equivalent experiments were conducted in 2015, except for the number of fish.

The surveys of infection rates by fish farm revealed an infection rate of $18.3 \sim 71.6 \%$ in 2014 and $16.3 \sim 90.3 \%$ in 2015 . These results suggest an increasing rate of emaciation infection and confirm the disease is a serious issue in the aquaculture industry in Jeju. It is considered that countermeasures, such as isolating the infected water tanks through regular monitoring, are needed to minimize the damage caused by emaciation.

In 2014, emaciation occurrence was mostly found in fish sized between 11 30 cm (Table 4). A similar result was found in 2015 but showed high infection rates even in larger sized fish $(>31 \mathrm{~cm})$ (Table 5). These results suggest that the infection rate of emaciation is relatively increased in adult fishes. However, a direct comparison of the infection rate by fish size is not possible due to the differences in the collected sampling number of fish. There are limited studies on this topic, and therefore, an absolute comparison is not feasible. However, it is considered necessary that particular attention is focused on the disease management throughout the life of the fish, as all the fish were susceptible to the emaciation infection irrespective of size.

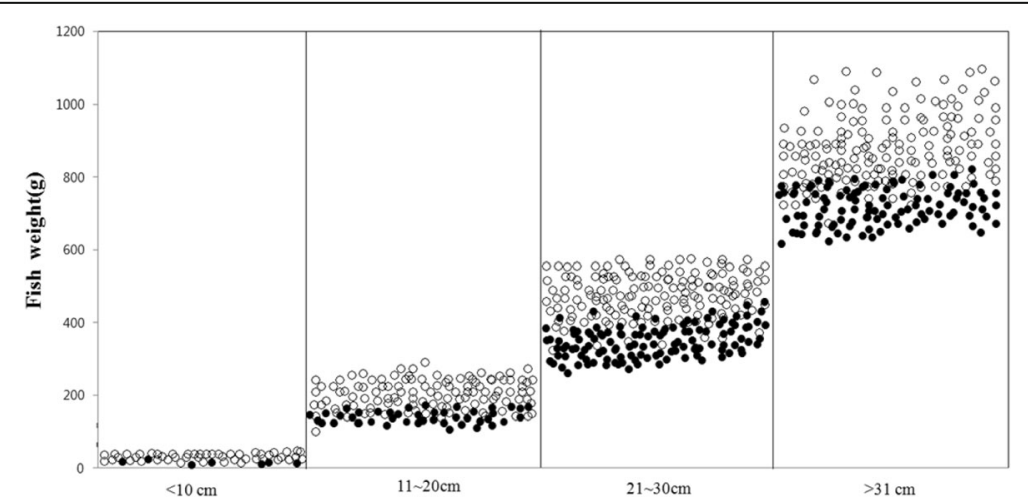

Fig. 3 Comparison of fish weight between PCR positive-olive flounder (black circle) and PCR negative-olive flounder (white circle) with the EM-F/ R primer set 

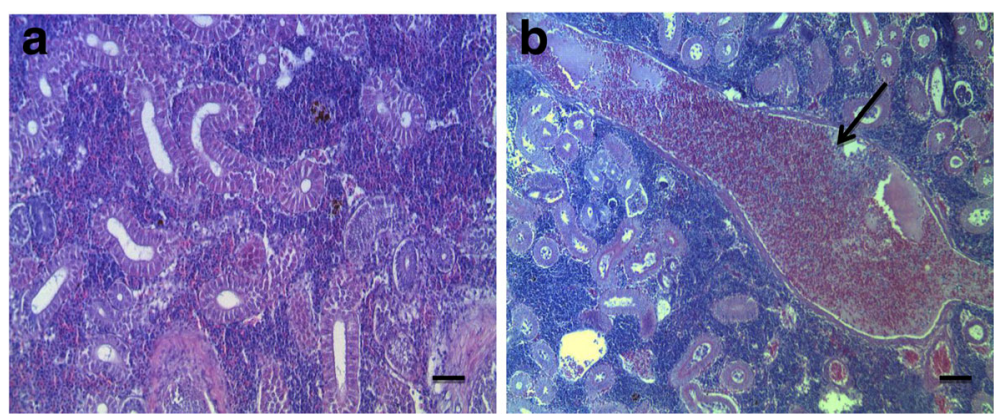

Fig. 4 Histological changes in the kidney of the olive flounder, Paralichthys olivaceus. a normal olive flounder ( $\times 100)$; $\mathbf{b}$ emaciated olive flounder ( $\times 100)$. Note microsporean spores in emaciated disease the gloerulus (arrow). H \& E stain. Bar $=20 \mu \mathrm{m}$

Infection rate of emaciation disease according to olive flounder weight showed that olive flounder of PCR positive with the EM-F/R primer set were lighter compared to olive flounder of PCR negative (Fig. 3). This finding was consistent with one proposed by Kim et al. (2015). The result is expected to be used as basic data for evaluating pathological characteristics in accordance with pathogenicity. More systematic research should be conducted in the correlation between the drop of fish with emaciation disease and pathogenicity of pathogens.

A statistical epidemiological survey on diseases of olive flounders by Kim et al. (2010) found that the infection rate of Trichodina and Ichthyobodo parasitic diseases was highest in April and December when the fluctuation of water temperature was high. As a result of the occurrence trends by period, relatively high rates of infection were observed in September and December 2014 and in March, July, and October 2015, which are before and after the high fluctuation of water temperature. However, infection occurred in all periods examined. Therefore, it is assumed that the seasonal fluctuation of water temperature in Jeju might not be one of the main causes of the yearly occurrence of emaciation.

This study provides useful and fundamental reference data on the epidemiology of emaciation infection in olive flounders cultivated within Jeju. Henceforth, studies on the life cycle of parasites that cause emaciation should be conducted.

\section{Conclusions}

We investigated the emaciation infection rates in cultured olive flounder of Korea, during 2014-2015 and the infection occurred in all of fish sizes throughout all the periods. It will be useful to research the emaciation disease in olive flounder of Korea.

\section{Abbreviations}

H\&E: Hematoxylin and Eosin; PCR: Polymerase chain reaction

\section{Funding}

This work was supported by the research grant of Jeju National University in 2015.
Availability of data and materials

All datasets generated during and/or analyzed during the current study are available from the corresponding author on reasonable request.

\section{Authors' contributions}

SMK conducted the research, analyzed the samples, and prepared the draft manuscript. LJJ, DWL, and HKP helped in the research conduction and statistical analysis. HDJ and JSK reviewed the manuscript. JJB designed the experiment and finalized the draft manuscript. All authors read and approved the final manuscript.

Ethics approval and consent to participate

Not applicable.

\section{Consent for publication}

Not applicable.

\section{Competing interests}

The authors declare that they have no competing interests.

\section{Publisher's Note}

Springer Nature remains neutral with regard to jurisdictional claims in published maps and institutional affiliations.

\section{Author details}

${ }^{1}$ Faculty of Marine Biomedical Science, Jeju National University, Jeju 63243, South Korea. ${ }^{2}$ Pathology Division, National Fisheries Research and Development Institute, Busan 63243, South Korea. ${ }^{3}$ Department of Microbiology \& Immunology, Dalhousie University, Halifax, Canada.

Received: 14 December 2017 Accepted: 16 March 2018

Published online: 25 June 2018

\section{References}

Cho MY, Jee BY, Park GH, Lee CH, Lee DC, Kim JW, Park MS, Park MA. Monitoring of fish pathogens in wild marine fish of Korean coastal offshore water in 2008. J Fish Pathol. 2009;22:75-83.

Cho MY, Kim MS, Choi HS, Park GH, Kim JW, Park MS, Park MA. A statistical study on infectious diseases of cultured olive flounder, Paralichthys olivaceus in Korea. J Fish Pathol. 2008;21:271-8.

Chun SK. Fish parasitology. Kor susantimes; 2006. p. 11-68.

Ishimatsu A, Hayashi M, Nakane M, Sameshima M. Pathophysiology of cultured tiger puffer Takifugu rubripes suffering from the myxosporean emaciation disease. Fish Pathol. 2007;42:211-7.

Jung SH, Choi HS, Jeung WD, Kim MS, Kwon MG, Seo JS, Hwang JY, Kim SR, Cho YR, Kim JD, Park MA, Jee BY, Cho MY, Kim JW. Monitoring of bacteria and parasites in cultured olive flounder, black rockfish, red sea bream and shrimp during summer period in Korea from 2007 to 2011. J Fish Pathol. 2012;25:231-41.

Katharios P, Kokkari C, Sterioti A, Smyrli M, Kalatzis P. Enteromyxum leei infection in parrotfish, Sparisoma cretense: histopathological, morphological and molecular study. Vet Parasitol. 2014;199:136-43. 
Kim JW, Cho MY, Park GH, Won KM, Choi HS, Kim MS, Park MA. Statistical data on infectious diseases of cultured olive flounder Paralichthys olivaceus form 2005 to 2007. J Fish Pathol. 2010;23:369-77.

Kim JW, Jung SH, Park MA, Do JW, Choi DL, Jee BY, Cho MY, Kim MS, Choi HS, Kim YC, Lee JS. Monitoring of pathogens in cultured fish of Korea for the summer period from 2000 to 2006. J Fish Pathol. 2006;19:207-14.

Kim SM, Jun LJ, Park MA, Jeong HD, Jeong JB. Characterization of the myxosporean parasite isolated from emaciated olive flounders Paralichthys oliveceus on Jeju island. J Fish Aquat. 2015;48:337-45.

OIE. Guidelines for aquatic animal health surveillance. In: Aquatic animal health code. eleventh ed. Paris: World organization for animal health; 2008. p. 245

Song JY, Choi JH, Choi HS, Jung SH, Park MA. Monitoring of Kudoa septempunctata in cultured olive flounder and wild fish in Jeju Isiand during 2012. J Fish Pathol. 2013;26:129-37.

Yasuda H, Ooyama T, Nakamura A, Iwata K, Palenzuela O, Yokoyama H. Occurrence of the myxosporean emaciation disease caused by Enteromyxum leei in cultured Japanese flounder Paralichthys olivaceus. Fish Pathol. 2005;40:175-80.

Submit your next manuscript to BioMed Central and we will help you at every step:

- We accept pre-submission inquiries

- Our selector tool helps you to find the most relevant journal

- We provide round the clock customer support

- Convenient online submission

- Thorough peer review

- Inclusion in PubMed and all major indexing services

- Maximum visibility for your research

Submit your manuscript at www.biomedcentral.com/submit
Biomed Central 